\title{
Water Quality of Mantayupan River in Barili, Cebu, Philippines
}

\author{
Alfredo C. Neri, Virgie P. Wee and Glenn B. Hoyohoy ${ }^{2}$ \\ 1 \\ Cebu Technological University - Barili Campus, Barili, Cebu, \\ Cebu Technological University - Moalboal Campus, Moalboal, Cebu
}

\begin{abstract}
The Mantayupan River is among the most important sources of water in Cebu, Philippines. This study was conducted to evaluate the physical, chemical, and microbiological characteristics of this river ecosystem and monitor the uses of its water. Results showed that Mantayupan river's overall water quality index (WQI) indicated only a "medium or average water quality" at the head water all the way down the river channel during dry season. In the rainy season, the river's WQI scaled a "good water quality" at the head water and falls but declined to "medium or average water quality" at its downstream. Results indicated that bathing or any recreational water contact activity is safe only during the wet season at the head water up to the Mantayupan falls but not after and until the downstream. However, the denser population of coliforms along the river indicates that Mantayupan falls situated closer to the head water than the downstream is not suitable for bathing and any recreational water contact activity during both seasons.
\end{abstract}

Keywords: Water quality, river pollution, water uses, eco-tourism

Correspondence: A. C. Neri. Address: Cebu Technological University-Barili Campus, Barili, Cebu City.E-mail: fred-neri@yahoo.com.

DOI: 10.32945/atr3426.2012 


\section{INTRODUCTION}

Water is vital to humans. It is needed for food preparation, drinking, washing, bathing, and irrigation. Although it has been a common knowledge that two-thirds of the earth is composed of water, it is not always discussed as to how much of it is fresh. Massive quantities of water are used daily in household, agriculture, and industrial processes. Yet, it is a limited resource that must be collected and distributed with increasing care. Efficient water management involves economic, social, and intangible values. Development of a river system for different usage sometimes generates conflicts with other water usage like irrigation and navigation, hydropower against our environmental concerns such as national parks, wilderness and historical resources.

The use of river systems by humankind has changed over the course of human history. The earliest use was as areas for human settlements providing water for domestic consumption and irrigation for agriculture and for trade and commerce that linked these settlements to the source of goods coming in from various areas far and near (Dynesius and Nilsson, 1994). The Ifugaos in the Philippines used the abundant natural springs in their mountains to help build and sustain the Banaue rice terraces. While people in other parts of the country have abundant sources of fresh water, others must fetch water in distant wells or rivers in order to survive. River systems generally originate from forested hinterlands that serve as nutrients source and they are connected to oceans making them areas of organic production and thus became a source of food, primarily fish (Vannote et al., 1980). In the $20^{\text {th }}$ century, scientists became worried about the rapid destruction of aquatic biodiversity, the increased frequency and magnitude of flooding, the erosion of uplands, the forest denudation in the watersheds, the increasing loss of resources from river systems, the deteriorating water quality of rivers due to pollution, among others which reduced the values of rivers as one of the major components of the earth's biosphere (Collier et al., 2000). At present, river systems are threatened by climate change (Hong et al., 1995).

Water pollution results in poor water quality and is harmful to living things. In severe cases, water pollution can kill large number of fish, birds, and other animals and sometimes all members of a species in an affected area. Pollution makes streams, lakes, and coastal waters unpleasant to look at, to smell, and to swim in. Fish and shellfish harvested from polluted waters may be unsafe to eat. People who ingest polluted water can become ill, and, with prolonged exposure, may develop cancers or bear children with birth defects. 
Meeting water quality expectations for streams and rivers is required to protect drinking water resources, encourage recreational activities, and provide a good environment for fish and wildlife (Said et al, 2004). Water quality is the physical, chemical and biological characteristics of water. It is a measure of the condition of water relative to the requirements of one or more biotic species and or to any human need or purpose. It is most frequently used by reference to a set of standards against which compliance can be assessed. The most common standards used to assess water quality relate to health of ecosystems, safety of human contact and drinking water.

In the municipality of Barili, Mantayupan River is one of the sources of water for domestic, agricultural, and industrial purposes. The local government considered it as a pride because along its stretch channels the well-known Mantayupan Falls, a waterfall which has become the municipality's main tourist attraction. A fractional water volume above the waterfall is utilized to power a mini-hydro plant to supplement the increasing need for electricity in the municipality. The tail water of the plant and waterfalls is diverted to irrigate rice fields. As in most local natural waterways, Mantayupan River is not spared from contamination. Little information has been known about any sustaining program for monitoring and protection of the river ecosystem. Specifically, no study has yet been conducted on assessing the water quality of the Mantayupan River. The increasing harmful effects of the river's contamination, if not suppressed, may eventually render it unfit for all of its purposes in the near future.

\section{RESEARCH METHODOLOGY}

\section{The Research Site}

Figure 1 shows the province of Cebu where the municipality of Barili is located. The topographic map of the municipality of Barili indicates the Mantayupan River which is the site of the study. Sampling sites were identified along the river system as follows: 1) head water, 2) Mantayupan falls, and 3) downstream. Mantayupan river stretched about $5 \mathrm{~km}$ from the head water to the downstream sampling site. 


\section{Research Method}

This study used the descriptive research method. On-site survey of the Mantayupan river was done to gather the primary data for the study. Secondary data were collected from the Municipal's Planning and Development Office (MPD0), Department of Tourism - Municipal Office, and Campangga Multi-purpose Cooperative (CAMPCO) of Barili, Cebu.

\section{Reconnaissance Survey of the River System}

A reconnaissance survey of the Mantayupan River ecosystem was done from the river head water down to its tail end (downstream) where sea water reached during high tide. This was done with the aid of a Site Topographic Map obtained from the MPDO. With this reconnaissance survey, existing uses of water from the river such as for crop irrigation and mini-hydro electric power generation was validated and other uses were identified. Results of the survey were used as bases for the identification of sampling sites.

\section{Identification of Sampling Sites}

Considering the 6-km stretch of the Mantayupan River channel, 3 locations were identified in taking water samples for physico-chemical and microbiological laboratory analyses. This included the river's major head water, the Mantayupan Falls, and the downstream where sea water reached during high tide. The head water is about $2 \mathrm{~km}$ above the Mantayupan Falls and the downstream is $3 \mathrm{~km}$ below the water falls. Other physical measurements of the river system were also done on these 3 sampling sites. 
Topographic Map of the Municipality of Barili

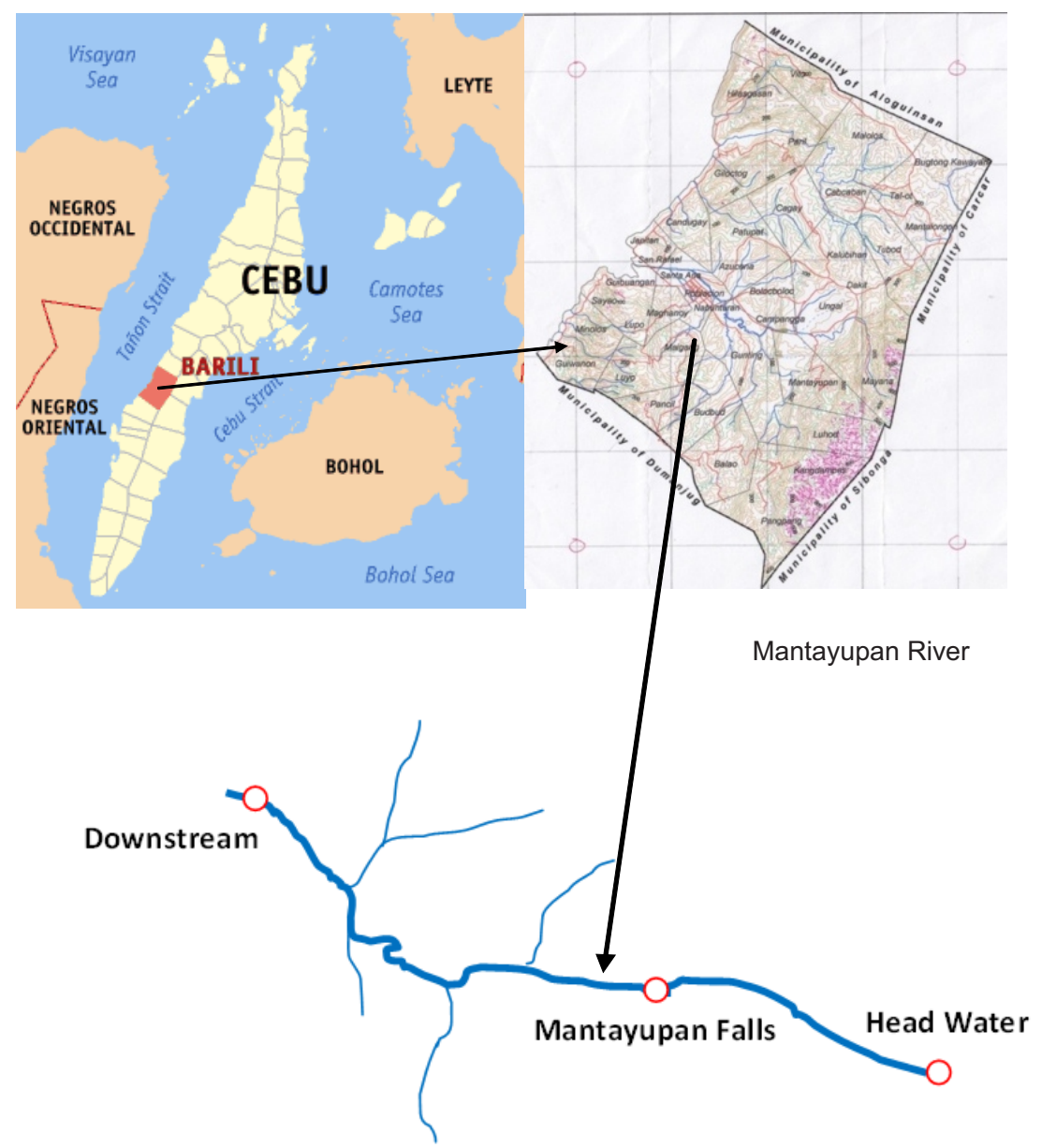

Figure 1. Map and sketch showing the sampling site along Mantayupan river in Barili, Cebu. 


\section{Sampling Method and Data Collection}

Water sampling and other measurements were done during the dry and rainy seasons. For the rainy season, water samples from the river were taken 3 days after a heavy rain that makes flood. This was to ensure that during that time, activities that relate to water use of the river got back to normal. Water samples were collected simultaneously from the 3 identified sampling sites along the river system. At each sampling site, the following river physical factors were directly measured: water temperature $\left({ }^{\circ} \mathrm{C}\right)$, river depth $(\mathrm{m})$, river width $(\mathrm{m})$, and water flow rate $(\mathrm{m} / \mathrm{s})$. For the water physical and chemical characteristics like $\mathrm{pH}$, turbidity (NTU), total dissolved solids (mg solids/L), phosphate $(\mathrm{mg} \mathrm{P} / \mathrm{L})$, nitrates $(\mathrm{mg} / \mathrm{L})$, dissolved oxygen $\left(\mathrm{mg} \quad \mathrm{O}_{2} / \mathrm{L}\right)$, and biochemical oxygen demand $\left(\mathrm{mg} \mathrm{O}_{2} / \mathrm{L}\right)$, water samples were obtained following the standard water sampling procedure. Likewise, for the microbiological factors such as fecal coliforms and total coliforms (MPN/100 $\mathrm{mL}$ ), separate water samples were taken still following the standard procedure.

\section{Sampling Procedure}

Water samples from the sampling sites were immediately brought to a DENR-accredited water resource laboratory for physico-chemical and microbiological tests or analyses. To ensure integrity of the samples or reliability and interpretability of the collected data, the following were the procedures applied in collecting water samples for each of the identified tests and in measuring water temperatures as extracted from the Methodology for the Sampling of Surface Waters (Minerals and Energy Advisory \#:AA7-025, March 2009).

\section{A. Physical and chemical tests}

1. Water samples were collected by submerging the clean containers to a depth of about $20 \mathrm{~cm}$ with the mouth facing upward or facing towards the water current. (This was done to prevent entry of floating or suspended undesirable particles to the sample container.)

2. Containers were filled with water leaving a small air space to facilitate shaking during transport. Each container was covered and labeled properly.

3. After the collection, the water samples were immediately transported to the laboratory for analyses. For Dissolved Oxygen (DO) test, the required 
time of 5-6 hours prior to analysis was considered. Thus, transport of the water samples was assured not to exceed the required time.

B. Microbiologicaltest

1. Sterilized bottles were used in collecting water samples for microbiological tests. In this study, sterilized containers were provided by the accredited water resource laboratory where water samples were submitted for analyses. Two bottles were used for this test per sampling site.

2. Bottles were filled with water by holding the lower part, immersing them completely with the mouth facing upwards. As the bottle was fully filled, few water volume was discarded providing air space to facilitate shaking prior to analysis.

3. Each of the bottles containing the water samples was covered and was also properly labeled.

4. Together with the containers for the other test, the bottles were transported immediately to the laboratory.

Water temperature. A laboratory thermometer was immersed below the surface of water on the river to determine its temperature, in Celsius scale/reading. This was done in several trials at each sampling site.

\section{Water Use Monitoring}

Uses of water in and from the river system were determined during the study. Monitoring activities included ocular surveys, informal interviews with direct users, and gathering of relevant information from the above-mentioned institutions/organizations.

\section{Statistical Analyses}

Descriptive statistical tools were used to analyze and interpret the results of the study. Specifically, the water quality index (WQI) protocol developed by Oram (2010) was applied to describe the water quality based on the physico-chemical and microbiological characteristics of water in the river ecosystem. To calculate the overall WQI, the results of 9 water quality parameters analyzed were used. These included the BOD, 
DO, fecal coliforms, nitrates, $\mathrm{pH}$, temperature change, total dissolved solids, total phosphate, and turbidity. The WQI protocol uses a scale from 0 to 100 to rate the quality of fresh surface waters, with 100 being the highest possible score (Table 1). Once the overall WQI score is known, it can be compared against the following scale to determine how healthy the water is on a given time.

The data were further statistically analyzed through two-factor ANOVA to determine significant differences of the water quality test parameters used between sampling sites and seasons.

Table 1. The WQI rating scale, description, and interpretation

\begin{tabular}{cll}
\hline Rating & \multicolumn{1}{c}{ Description } & \multicolumn{1}{c}{ Interpretation } \\
\hline $91-100$ & Excellent water quality & $\begin{array}{l}\text { Able to support a high diversity of aquatic } \\
\text { life and suitable for all forms of } \\
\text { recreation, including those involving } \\
\text { direct contact with the water }\end{array}$ \\
\hline $71-90$ & Good water quality & $\begin{array}{l}\text { Have less diversity of aquatic organisms } \\
\text { and frequently have increased algae } \\
\text { growth }\end{array}$ \\
\hline $51-70$ & Medium or average water quality \\
\hline $26-50$ & Fair water quality & $\begin{array}{l}\text { Able to support a low diversity of aquatic } \\
\text { life and are probably experiencing } \\
\text { problems with pollution }\end{array}$ \\
\hline $0-25$ & Poor water quality & $\begin{array}{l}\text { May only be able to support a limited } \\
\text { number of aquatic life forms, have } \\
\text { abundant quality problems, and not } \\
\text { normally acceptable for activities } \\
\text { involving direct contact with the water, } \\
\text { such as swimming }\end{array}$ \\
\hline
\end{tabular}




\section{RESULTS AND DISCUSSIONS}

\section{Physical and Biochemical Characteristics of Mantayupan River}

Survey results showed that Mantayupan River has an average water discharge of 356 liters/sec at its major head water. It is increased by about $18 \%$ or 420 liters/sec at its lowest downstream due to 4 smaller tributary streams channeled to and along the river system. The river stretched about $6 \mathrm{~km}$ from the head water to the seashore where it empties. The river head water has an elevation of about $200 \mathrm{~m}$ above sea level while the top of Mantayupan falls is elevated at about $115 \mathrm{~m}$. The longest vertical span among the three (3) stages of Mantayupan falls is 98 meters.

Water quality index (WQI), as a measure of the physico-chemical and microbiological characteristics, indicates a "medium or average water quality" (70.08) of water sampled from Mantayupan river head water during dry season (Table 2). Factor identified that influenced the reduction of river water quality is the count of fecal coliforms (230), as this exceeds the water quality criteria set by the Department of Environment and Natural Resources (DENR) (DAO No. 34 s. 1990) for a recreational fresh surface water classification. On the other hand, in the wet season, the WQI of 74.65 indicates a "good water quality" since there were lesser colonies of fecal coliforms (79) during that time. Among the test parameters used, the dissolved oxygen contributed the highest fraction (13.60 and 12.41) to the overall WQI of the river in both seasons, respectively. This result indicates that this part of the river would be able to support a high diversity of aquatic life and would be suitable for all forms of recreation and direct contact with the water only during wet or rainy season. 
Table 2. Calculated water quality index (WQI) of Mantayupan river head water in dry season and wet season

\begin{tabular}{|c|c|c|c|c|c|c|c|c|}
\hline \multirow[b]{2}{*}{ Test Parameter } & \multicolumn{2}{|c|}{ Test Results } & \multirow{2}{*}{$\begin{array}{l}\text { DENR } \\
\text { Require- } \\
\text { ment }\end{array}$} & \multicolumn{2}{|c|}{ Q-value } & \multirow{2}{*}{$\begin{array}{l}\text { Weighing - } \\
\text { Factor }\end{array}$} & \multicolumn{2}{|c|}{ Total } \\
\hline & $\begin{array}{c}\text { Dry } \\
\text { Season }\end{array}$ & $\begin{array}{c}\text { Wet } \\
\text { Season }\end{array}$ & & $\begin{array}{c}\text { Dry } \\
\text { Season }\end{array}$ & $\begin{array}{c}\text { Wet } \\
\text { Season }\end{array}$ & & $\begin{array}{c}\text { Dry } \\
\text { Season }\end{array}$ & $\begin{array}{c}\text { Wet } \\
\text { Season }\end{array}$ \\
\hline BOD (mg/L) & 1.15 & 0.25 & 5 & 90 & 98 & 0.11 & 9.90 & 10.78 \\
\hline $\begin{array}{l}\text { Dissolved oxygen } \\
\text { (\% saturation) }\end{array}$ & 75.15 & 71.70 & 70 & 80 & 73 & 0.17 & 13.60 & 12.41 \\
\hline $\begin{array}{l}\text { Fecal coliforms } \\
\text { (colonies/100 mL) }\end{array}$ & 230 & 79 & 200 & 36 & 49 & 0.16 & 5.76 & 7.84 \\
\hline Nitrates (mg/L) & 79 & 28 & NR & 4 & 30 & 0.10 & 0.40 & 3.00 \\
\hline $\mathrm{pH}$ & 6.95 & 7.00 & $6.5-8.5$ & 88 & 89 & 0.11 & 9.68 & 9.79 \\
\hline Temperature $\left({ }^{\circ} \mathrm{C}\right)$ & 1 & 1 & 3 & 90 & 90 & 0.10 & 9.00 & 9.00 \\
\hline $\begin{array}{l}\text { Total dissolved } \\
\text { solids }(\mathrm{mg} / \mathrm{L})\end{array}$ & 277 & 281 & -- & 62 & 61 & 0.07 & 4.34 & 4.27 \\
\hline $\begin{array}{l}\text { Total phosphate } \\
(\mathrm{mg} / \mathrm{L})\end{array}$ & 0.009 & 0.009 & 0.20 & 98 & 98 & 0.10 & 9.80 & 9.80 \\
\hline \multirow[t]{2}{*}{ Turbidity (NTU) } & 1.66 & 0.74 & -- & 95 & 97 & 0.08 & 7.60 & 7.76 \\
\hline & & & & \multicolumn{3}{|c|}{ Overall WQI } & 70.08 & 74.65 \\
\hline
\end{tabular}

Q-values determined from Graphs included in the WQI Protocol (Oram, 2010)

Weighing factors are also obtained from same WQI Protocol

The calculated WQIs at Mantayupan Falls indicate a little difference in water qualities (70.20 and 71.85) between dry season and wet season (Table 3). However, the WQI during dry season still fall under "medium or average water quality" while "good water quality" in wet season. The dominant factors that influenced this reduction compared to water quality at the head water are the increased count of fecal coliforms in the dry season (3300) and the increased total dissolved solids (214) in the wet season. However, it is still the dissolved oxygen (15.81 and 15.30) that contributed the highest part to the river's WQI while BOD (10.89 and 10.34) contributed next in both seasons, respectively. This result implies that Mantayupan falls is suitable for all forms of recreation and direct contact with the water only during wet season and at its critical condition during dry season. 
Table 3. Calculated water quality index (WQI) of Mantayupan falls in dry season and wet season.

\begin{tabular}{|c|c|c|c|c|c|c|c|c|}
\hline \multirow[b]{2}{*}{ Test Parameter } & \multicolumn{2}{|c|}{ Test Results } & \multirow{2}{*}{$\begin{array}{l}\text { DENR } \\
\text { Require- } \\
\text { ment }\end{array}$} & \multicolumn{2}{|c|}{ Q-value } & \multirow{2}{*}{$\begin{array}{l}\text { Weighing } \\
\text { Factor }\end{array}$} & \multicolumn{2}{|c|}{ Total } \\
\hline & $\begin{array}{c}\text { Dry } \\
\text { Season }\end{array}$ & $\begin{array}{c}\text { Wet } \\
\text { Season }\end{array}$ & & $\begin{array}{c}\text { Dry } \\
\text { Season }\end{array}$ & $\begin{array}{c}\text { Wet } \\
\text { Season }\end{array}$ & & $\begin{array}{c}\text { Dry } \\
\text { Season }\end{array}$ & $\begin{array}{c}\text { Wet } \\
\text { Season }\end{array}$ \\
\hline BOD $(\mathrm{mg} / \mathrm{L})$ & 0.15 & 0.7 & 5 & 99 & 94 & 0.11 & 10.89 & 10.34 \\
\hline $\begin{array}{l}\text { Dissolved oxygen } \\
\text { (\% saturation) }\end{array}$ & 89.30 & 85.30 & 70 & 93 & 90 & 0.17 & 15.81 & 15.30 \\
\hline $\begin{array}{l}\text { Fecal coliforms } \\
\text { (colonies/100 mL) }\end{array}$ & 3300 & 330 & 200 & 16 & 34 & 0.16 & 2.56 & 5.44 \\
\hline Nitrates (mg/L) & 1103 & 112 & NR & 1 & 1 & 0.10 & 0.10 & 0.10 \\
\hline $\mathrm{pH}$ & 7.78 & 7.73 & $6.5-8.5$ & 86 & 85 & 0.11 & 9.46 & 9.35 \\
\hline Temperature $\left({ }^{\circ} \mathrm{C}\right)$ & 1 & 1 & 3 & 90 & 90 & 0.10 & 9.00 & 9.00 \\
\hline $\begin{array}{l}\text { Total dissolved } \\
\text { solids }(\mathrm{mg} / \mathrm{L})\end{array}$ & 190 & 214 & -- & 72 & 70 & 0.07 & 5.04 & 4.90 \\
\hline $\begin{array}{l}\text { Total phosphate } \\
(\mathrm{mg} / \mathrm{L})\end{array}$ & 0.005 & 0.005 & 0.20 & 99 & 99 & 0.10 & 9.90 & 9.90 \\
\hline \multirow[t]{2}{*}{ Turbidity (NTU) } & 2.9 & 1.78 & -- & 93 & 94 & 0.08 & 7.44 & 7.52 \\
\hline & & & & \multicolumn{3}{|c|}{ Overall WQI } & 70.20 & 71.85 \\
\hline
\end{tabular}

Q-values determined from Graphs included in the WQI Protocol (Oram, 2010)

Weighing factors are also obtained from same WQI Protocol

Table 4 shows a more reduced water quality at Mantayupan River downstream (65.59 and 64.80, respectively) in dry and wet seasons both falling on the "medium or average water quality" scale. This is due to the significant increase in population of fecal coliforms (23000) which is about a hundred times the DENR requirement. Also, total dissolved solids (287 and 316 ) and turbidity values (7.33 and 7.49) in this river site are higher in both seasons, respectively. The overall WQI indicates that this part of the river have less diversity of aquatic organisms and frequently have increased algae growth which may hinder suitability for any water contact activity in any season. 
Table 4. Calculated water quality index (WQI) of Mantayupan river downstream in dry season and wet season.

\begin{tabular}{|c|c|c|c|c|c|c|c|c|}
\hline \multirow[b]{2}{*}{ Test Parameter } & \multicolumn{2}{|c|}{ Test Results } & \multirow{2}{*}{$\begin{array}{c}\text { DENR } \\
\text { Require- } \\
\text { ment }\end{array}$} & \multicolumn{2}{|c|}{ Q-value } & \multirow{2}{*}{$\begin{array}{l}\text { Weighing } \\
\text { Factor }\end{array}$} & \multicolumn{2}{|c|}{ Total } \\
\hline & $\begin{array}{c}\text { Dry } \\
\text { Season }\end{array}$ & $\begin{array}{c}\text { Wet } \\
\text { Season }\end{array}$ & & $\begin{array}{c}\text { Dry } \\
\text { Season }\end{array}$ & $\begin{array}{c}\text { Wet } \\
\text { Season }\end{array}$ & & $\begin{array}{c}\text { Dry } \\
\text { Season }\end{array}$ & $\begin{array}{c}\text { Wet } \\
\text { Season }\end{array}$ \\
\hline BOD $(\mathrm{mg} / \mathrm{L})$ & 0.66 & 0.74 & 5 & 94 & 92 & 0.11 & 10.34 & 10.12 \\
\hline $\begin{array}{l}\text { Dissolved oxygen } \\
\text { (\% saturation) }\end{array}$ & 88.02 & 84.48 & 70 & 92 & 89 & 0.17 & 15.64 & 15.13 \\
\hline $\begin{array}{l}\text { Fecal coliforms } \\
\text { (colonies/100 mL) }\end{array}$ & 23000 & 23000 & 200 & 5 & 5 & 0.16 & 0.80 & 0.80 \\
\hline Nitrates (mg/L) & 7669 & 7669 & NR & 1 & 1 & 0.10 & 0.10 & 0.10 \\
\hline $\mathrm{pH}$ & 7.91 & 7.96 & $6.5-8.5$ & 85 & 85 & 0.11 & 9.35 & 9.35 \\
\hline Temperature $\left({ }^{\circ} \mathrm{C}\right)$ & 1.0 & 1.0 & 3 & 90 & 90 & 0.10 & 9.00 & 9.00 \\
\hline $\begin{array}{l}\text { Total dissolved } \\
\text { solids }(\mathrm{mg} / \mathrm{L})\end{array}$ & 287 & 316 & -- & 60 & 58 & 0.07 & 4.20 & 4.06 \\
\hline $\begin{array}{l}\text { Total phosphate } \\
(\mathrm{mg} / \mathrm{L})\end{array}$ & 0.018 & 0.018 & 0.20 & 96 & 96 & 0.10 & 9.60 & 9.60 \\
\hline \multirow[t]{2}{*}{ Turbidity (NTU) } & 7.33 & 7.49 & -- & 82 & 83 & 0.08 & 6.56 & 6.64 \\
\hline & & & & \multicolumn{3}{|c|}{ Overall WQI } & 65.59 & 64.80 \\
\hline
\end{tabular}

$Q$-values determined from Graphs included in the WQI Protocol (Oram, 2010)

Weighing factors are also obtained from same WQI Protocol

The calculated WQIs generally show a declining water quality of Mantayupan river from its head water to downstream (Fig. 2). A similar trend is observed in both dry and wet seasons. Specifically however, water qualities at Mantayupan head water and falls differ with seasons. They are mostly better during wet season. This implies that the river potentially may not be suitable for bathing or for any water contact activity after long dry season even at its head water. On the other hand, water contact activities are more appropriate few days after a rain during wet season along Mantayupan River from head water down but only until the Mantayupan Falls. 


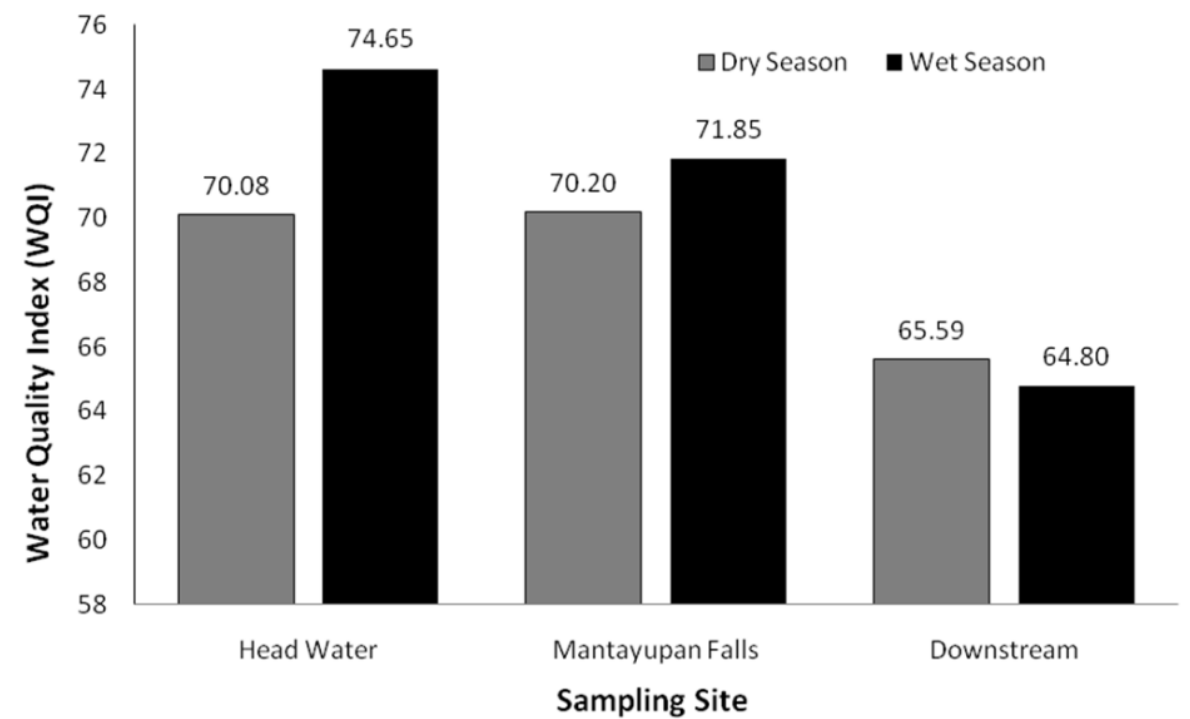

Figure 2. Water quality indices of Mantayupan river in different sampling sites and seasons.

Table 5 shows the result of the two-factor ANOVA on water quality test parameters between sampling sites and seasons. It revealed highly significant differences on dissolved oxygen, fecal coliforms, nitrates, and $\mathrm{pH}$ between sampling sites. While only significant differences on total dissolved solids and turbidity were observed between sampling sites. This supports the above implication that the water quality of the river system declines as it goes downstream. However, all the test parameters, except the dissolved oxygen, have shown no significant difference between seasons. This also suggests that even if it is only the dissolved oxygen that is highly significant between seasons, it is still critical to do any water contact activity during both seasons. 
Table 5. Comparison of water quality test parameters between sampling sites and seasons

\begin{tabular}{|c|c|c|c|c|c|c|c|}
\hline \multirow[b]{2}{*}{$\begin{array}{l}\text { Source of } \\
\text { Variation }\end{array}$} & \multicolumn{7}{|c|}{ Computed f-values of Test Parameters } \\
\hline & BOD & $\begin{array}{l}\text { Dissolved } \\
\text { Oxygen }\end{array}$ & $\begin{array}{c}\text { Fecal } \\
\text { Coliforms }\end{array}$ & Nitrates & $\mathrm{pH}$ & $\begin{array}{c}\text { Total } \\
\text { Dissolved } \\
\text { Solids }\end{array}$ & Turbidity \\
\hline Sampling Sites & $0.184^{\mathrm{ns}}$ & $2743.001^{* *}$ & $231.912^{* *}$ & $231.587^{* *}$ & $312.48^{* *}$ & $62.230^{*}$ & $92.194^{*}$ \\
\hline Seasons & $0.044^{\mathrm{ns}}$ & $462.582^{* *}$ & $1.161^{\mathrm{ns}}$ & $1.162^{\mathrm{ns}}$ & $0.25^{\mathrm{ns}}$ & $6.188^{\mathrm{ns}}$ & $2.485^{\mathrm{ns}}$ \\
\hline $\begin{array}{ll}* & \text { significant } \\
* * & \text { highly significant } \\
n s & \text { not significant }\end{array}$ & $\begin{array}{l}(f @ 5 \% \\
(f @ 1 \%\end{array}$ & $\begin{array}{l}\text { 9.00, sampli } \\
9.00 \text {, samplin }\end{array}$ & $\begin{array}{l}\text { sites; } f @ 5 \%= \\
\text { sites; f@1\%=1\%= }\end{array}$ & $\begin{array}{l}\text { 18.51, seasons } \\
8.50 \text {, seasons) }\end{array}$ & & & \\
\hline
\end{tabular}

Microbiological Characteristics of the River Ecosystem

Table 6 shows observable differences on the counts of fecal coliforms and total coliforms of water samples from the three (3) sampling sites identified in the study. Except at the head water during the wet season (79), all the sampling sites indicated higher fecal coliform counts during both seasons than the DENR set maximum limit for a Class B fresh surface water classification. Likewise, except at the head water, all the water samples taken from the sampling sites noted higher total coliform counts during both seasons than the DENR set maximum limit. There is an increasing trend in the counts of fecal coliforms and total coliforms as water goes downstream. This implies that certain activities and conditions above and along the river ecosystem may have enhanced the production of this microorganism. Statistical analysis through ANOVA reveals a significant difference only on fecal coliforms between sampling sites (Table 7).

Table 6. Fecal coliform and total coliform counts of water samples from sampling sites along Mantayupan river.

\begin{tabular}{lrrrr}
\hline \multirow{2}{*}{ Sampling Site } & \multicolumn{2}{c}{$\begin{array}{c}\text { Fecal Coliforms } \\
\text { (MPN/100 mL) }\end{array}$} & \multicolumn{2}{c}{$\begin{array}{c}\text { Total Coliforms } \\
\text { (MPN/100 mL) }\end{array}$} \\
\cline { 2 - 5 } & Dry Season & Wet Season & Dry Season & Wet Season \\
\hline Head Water & 230 & 79 & 460 & 330 \\
Mantayupan Falls & 3300 & 330 & 11000 & 23000 \\
Downstream & 23000 & 23000 & 23000 & 33000 \\
\hline $\begin{array}{l}\text { DENR Maximum Limit } \\
\text { (Class B) }\end{array}$ & \multicolumn{2}{c}{200} & & \multicolumn{2}{c}{1000} \\
\hline
\end{tabular}


Table 7. Comparison of water quality test parameters between sampling sites and seasons.

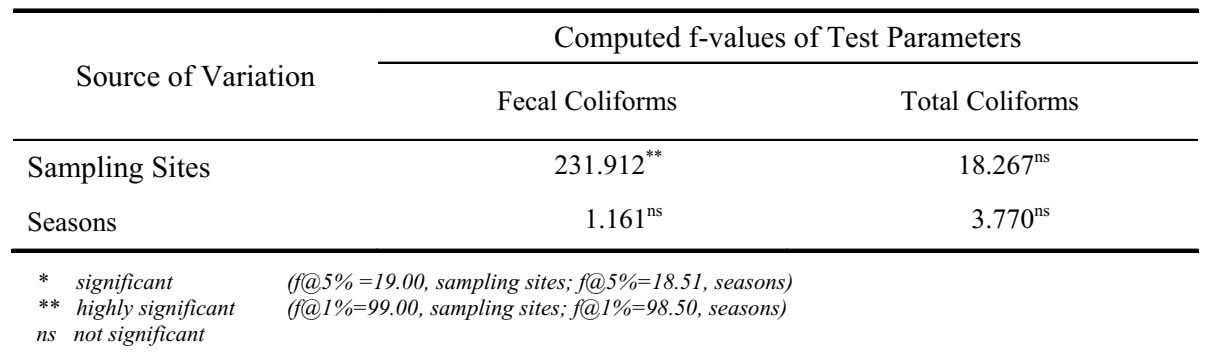

\section{Uses of Water in the River Ecosystem}

At the river's head water, water is used for drinking by the nearby residents (Table 8). Usually, water containers are dipped on a clear portion of about $6 \mathrm{~m}$ diameter and $1.5 \mathrm{~m}$ deep open wide spring since no drinking structure is made on this site. Washing of varied household and farm sorts is one of the major activities done all along the river channel. Bathing is mostly done at the head water down until Mantayupan Falls because the water quality down after the falls start to become fair. Swimming is done only at the head water and Mantayupan Falls as these are the portions only with favorable open water width and depth for the activity. Water diversion structures are also present on the river system since water is used to power a mini-hydro power plant, to irrigate crops, and to supply Tilapia fishponds. Excesses of the water used through diversions from the river were mostly rechanneled back to its closer river stream.

Table 8. Major uses of water in Mantayupan river ecosystem.

\begin{tabular}{ll}
\hline \multicolumn{1}{c}{ Use of Water } & \multicolumn{1}{c}{ Part of the River } \\
\hline Drinking & Head water \\
Washing of household and farm sorts & Head water to downstream \\
Bathing & Head water down to Mantayupan falls \\
Swimming & Head water and Mantayupan falls \\
Mini-hydro power plant & Diversion from upstream of Mantayupan falls \\
Irrigation system & Diversion from Mantayupan falls \\
Fishponds & Diversion from Irrigation system \\
\hline
\end{tabular}

a First hydro project established in Cebu (1984) connected to CEBECO II grid, water use schedule is at 5:00 PM to 5:00 AM daily (CAMPCCO, 2010). 


\section{CONCLUSIONS}

Mantayupan River's overall WQI indicated only a "medium or average water quality" at the head water all the way down the river channel as analyzed during dry season. However, in the rainy season, the river's WQI reached the minimum scale for a "good water quality" at the head water and falls but declined to "medium or average water quality" at its downstream. Therefore, it can be concluded that bathing or any recreational water contact activity is safe only during the wet season at the head water down until the Mantayupan falls but not after and until the downstream.

The population of fecal coliforms and total coliforms drastically increased beyond tolerable limits in water samples taken from Mantayupan falls and downstream during dry and wet seasons. This is strong evidence that Mantayupan falls is not even safe to bath and do any recreational direct water contact activity anytime during both seasons.

The major uses of water on and from Mantayupan river included that as a source or venue for bathing and washing of various household and farm sorts, mostly at the upstream near the major head water; as source of irrigation for rice farms; as source of hydropower for electricity generation in a local mini-hydro power plant; as a natural water falls which had become the municipality's tourist attraction; and as water supply to fishponds for Tilapia fun-fishing activities.

Since the study focused only on the above aspects, a follow-up study is recommended to evaluate the extent of water use and socio-economic activities along and above the Mantayupan river channel. Other biotic indicators on the river have to be assessed to determine their classification and population. Presence of other chemical characteristics like heavy metals also needs to be analyzed for any influence to the river's water quality and toxicity. Constant monitoring activities of the river's water quality have to be done to keep track of its status and safe use at specified time. Mitigating measures to improve the physical, chemical, and microbiological conditions of the river are also deemed necessary. 


\section{LITERATURE CITED}

COLLIER, M., R.H. WEBB, and J.C. SCHMIDT. 2000. Dams and rivers: $A$ primer on the downstream effects of dams. U.S. Department of Interior. 95p.

DYNESIUS, M. and C. NELSSON. 1994. Fragmentation and flow regulation of river systems in the Northern Third of the World. Science, 266: 753762.

HONG, G.H., S.H. KIM, C.S, CHUNG, and S.J. PAE. 1995. The role of the anthropogenic nutrient input in the carbon fixation of the Coastal Ocean Yellow Sea: A preliminary study. Direct Ocean Disposal of Carbon Dioxide. pp. 13-22.

MINERALS AND ENERGY ADVISORY. \#:AA7-025. March 2009. Methodology for the Sampling of Surface Waters. Mining Environmental Compliance. Department of Resources. GPO Box 3000, Darwin, Northern Territory 0801. Available at www.minerals.nt.gov.au

ORAM, B. 2010. The Water Quality Index: Monitoring the Quality of Surfacewaters. Water Research Center. B. F. Environmental Consultants Inc. 15 Hillcrest Drive, Dallas, PA 18612. Available from http://www.water-research.net/watrqualindex/waterquality index.htm

SAID, A., D.K. STEVEN and G. SEHLKE., 2004. Environmental Assessment: An Innovative Index for Evaluating Water Quality in Streams. Environmental Management, 34 (3), 406-414.

VANNOTE, R.L., G.W. MINSHALL, K.W. CUMMINS, J.R. SEDELLE and C.E. CUSHING. 1980. The river continuum concept. Canadian Journal of Fisheryand Aquatic Science, 37: 130-137. 